\title{
MGMT wt Allele
}

National Cancer Institute

\section{Source}

National Cancer Institute. MGMT wt Allele. NCI Thesaurus. Code C52085.

Human MGMT wild-type allele is located within $10 \mathrm{q} 26$ and is approximately $300 \mathrm{~kb}$ in length. This allele, which encodes methylated-DNA-protein-cysteine methyltransferase protein, plays a role in the repair of O6-alkylguanine residues in DNA. Expression of the MGMT gene is abrogated via promoter hypermethylation in certain types of cancer such as brain neoplasms, gastric cancer, hepatocellular carcinoma and non-small cell lung cancer. 